
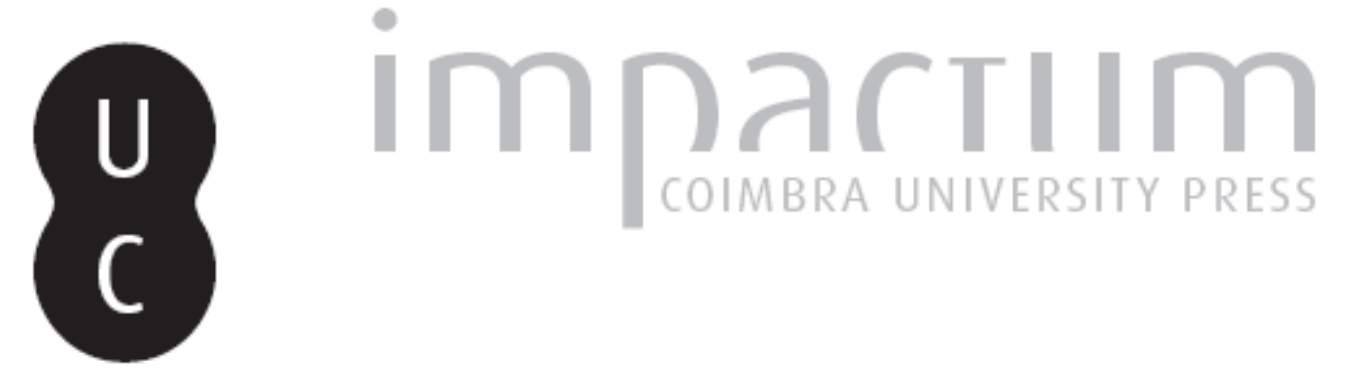

\title{
Mtis and violence in Machiavellian political theory
}

\section{Autor(es): Queiroz, Regina}

Publicado por: Imprensa da Universidade de Coimbra

URL persistente:

URI:http://hdl.handle.net/10316.2/42799

DOI:

DOI:https://doi.org/10.14195/1984-249X_21_7

Accessed : $\quad$ 26-Apr-2023 14:03:56

A navegação consulta e descarregamento dos títulos inseridos nas Bibliotecas Digitais UC Digitalis, UC Pombalina e UC Impactum, pressupõem a aceitação plena e sem reservas dos Termos e Condições de Uso destas Bibliotecas Digitais, disponíveis em https://digitalis.uc.pt/pt-pt/termos.

Conforme exposto nos referidos Termos e Condições de Uso, o descarregamento de títulos de acesso restrito requer uma licença válida de autorização devendo o utilizador aceder ao(s) documento(s) a partir de um endereço de IP da instituição detentora da supramencionada licença.

Ao utilizador é apenas permitido o descarregamento para uso pessoal, pelo que o emprego do(s) título(s) descarregado(s) para outro fim, designadamente comercial, carece de autorização do respetivo autor ou editor da obra.

Na medida em que todas as obras da UC Digitalis se encontram protegidas pelo Código do Direito de Autor e Direitos Conexos e demais legislação aplicável, toda a cópia, parcial ou total, deste documento, nos casos em que é legalmente admitida, deverá conter ou fazer-se acompanhar por este aviso.

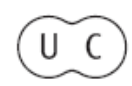




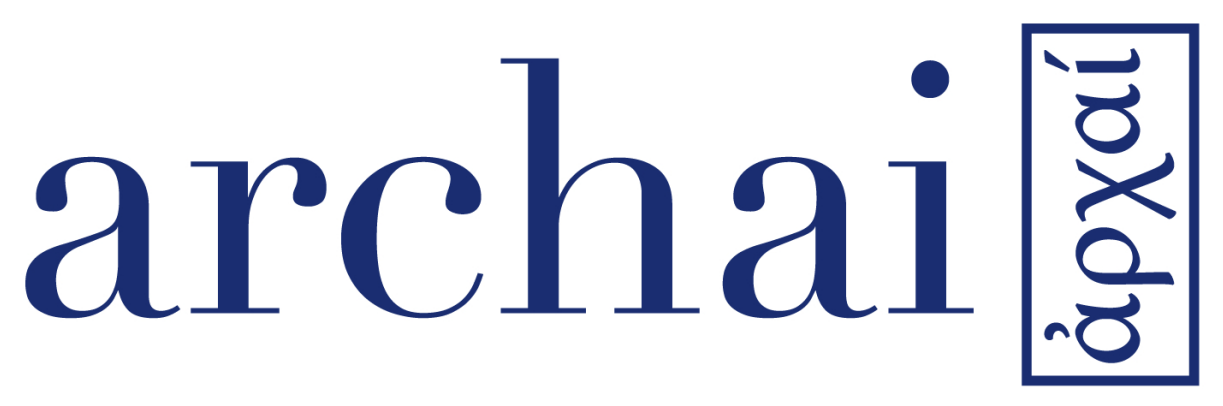

Revista sobre as origens do pensamento ocidental Journal on the Origins of Western Thought

21 | sep.-dec. 2017 


\section{Mētis ANd VIOLENCE IN MACH- IAVELLIAN POLITICAL THEORY}

\section{archai圈}

no 21, sep.-dec. 2017

QUEIROZ, R. (2017). Mètis and violence in Machiavellian political theory. Archai n²1, sep.-dec., p. 223-250

DOI: https://doi.org/10.14195/1984-249X_21_7

\begin{abstract}
The quest for winning and preserving political power in Machiavelli's The Prince is led by the bellicose version of the pre-classical and mythological concept of metis or cunning rationality. In opposition to a domestic version of cunning rationality, understood as the rationality of the weak, Machiavellian mètis is a prudential and deceptive rationality of the strong. Bellicose cunning rationality does not, however, prevent the prince from falling into the hubris of violence, and does not avoid undermining cunning rationality itself. Our article evaluates and circumscribes the contribution, as well as the theoretical and practical limits of the Machiavellian bellicose cunning rationality.
\end{abstract}

Keywords: Cunning rationality, hubris of violence, mètis, political power, prudence. 


\section{archai圈}

no 21, sep.-dec. 2017

Regina Queiroz, 'Mētis and violence in $\mathrm{Ma}$ chiavellian political theory', p. 223-250

\section{INTRODUCTION}

Although Machiavelli did not explicitly refer to mettis (or cunning rationality), the fox's attribution as an essential feature of the prince's rationality (Machiavelli, 1998 [1515], XVIII) allows for an understanding of Machiavellian political rationality as mètis. In the "Greek world, the fox is Cunning; in Greek a cunning trick can be called alopex or fox [...] [a fox has] a mind of many nuances and a polymorphic intelligence which can adapt to any circumstances" (Detienne \& Vernant, 1978 [1976], p. 35-36). That polymorphic intelligence includes prudence - " [...] mètis is an informed prudence" (Detienne \& Vernant, 1978 [1976], p. 27), which is the virtue or the excellence of political rationality in Machiavellian political theory (Pocock, 1975). Besides following mêtis, the well-known Machiavellian analogy between politics and war (Dietz, 1986; Lukes, 2004; Mansfield 1981), leads Machiavellian political thought to stress mètis' pre-classical and mythological bellicose version (Homer, 2003). In Machiavellian political thought bellicose cunning rationality is mostly the rationality of the strong and not the prudential rationality of the weak or the "art of the weak" (De Certeau, Jameson, and Lovitt, 1980, 6; see also Detienne \& Vernant, 1978 [1976]; Dobel, 2006, Herzog, 2006).

Nevertheless, since the bellicose appropriation of the bellicose version of the pre-classical cunning rationality seriously limits the influence of prudence in a prince's political reasoning, we wonder if Machiavellian appropriation of the pre-classical cunning rationality does not avoid the prince's fall into the hubris of violence. We also wonder if Machiavellian 
bellicose cunning rationality, as the rationality of the strong, does not undermine cunning rationality itself.

For instance, the unavoidable violence in Machiavellian political theory has already been stressed in philosophy and political theory literature (Arendt, 1954; Baker, 2009; Frazer and Hutchings, 2011; Minter, 1991; Tarlton, 2003; Wolin, 2004). The relationship between that violence and cunning rationality or mêtis has received little attention, however. It is true that some authors (Detienne \& Vernant, 1978 [1976]; De Certeau, Jameson, and Lovitt, 1980; Dobel, 2006; Herzog, 2006; Nikodimov, 2006) have referred to the importance of mettis in Machiavellian thought. Herzog (2006) related mètis to cruelty and De Certeau, Jameson, and Lovitt (1980) with tactics. However, these approaches did not sufficiently stress the relationship between Machiavelli's bellicose understanding and the hubris of violence.

A comprehension of the relationship between the hubris of violence and bellicose mettis seems, however, important. First, it clarifies how the prudential nature of mettis is undermined by the bellicose understanding of cunning rationality. Second, the comprehension of the relationship between the hubris of violence and mêtis seems also to circumscribe the contribution, as well as the limits, of Machiavellian cunning rationality for the quest for winning and preserving political power.

Based only on Machiavellian political theory issues presented in The Prince and with the main aims stated above, we analyze the bellicose Machiavellian concept of mêtis as well as the difficulties of basing political

\section{archai葶}

no 21, sep.-dec. 2017

Regina Queiroz, 'Mētis and violence in Machiavellian political theory', p. 223-250 


\section{archai 國}

no 21, sep.-dec. 2017

Regina Queiroz, 'Mētis and violence in $\mathrm{Ma}$ chiavellian political theory', p. 223-250 practice on the bellicose pre-classical conception of rationality. In the first paragraph we will briefly describe the pre-classical and mythological concept of mètis. In the second we will clarify the bellicose Machiavellian understanding of mētis, emphasizing the importance of prudence of the excellence of cunning rationality. In the third we will present the main problems with bellicose understanding of metis, as the rationality of the strong, namely the fall into the hubris of violence. We also compare the bellicose understanding of métis (Homer, 2003; see also Machiavelli, 1998 [1515]), as the rationality of the strong, with the domestic version as the rationality of the weak (Homer, 1996; see also De Certeau, Jameson, and Lovitt, 1980, and Detienne \& Vernant, 1978 [1976]).

In this analysis we will not dwell on the difference between actual violence and mind violence (Machiavelli, 1998 [1515], IX, p. 60). What is at stake in our essay is the concept of rationality in Machiavellian political thought. In this analysis we also consider neither Machiavelli as a political actor (Benner, 2014; Dietz, 1986; Wolin, 1960), nor The Prince as a political act of deception (Dietz, 1986), the realistic or rhetorical nature of Machiavellian political theory (Hariman, 1995), and the apparent discrepancies between the Discourses (Machiavelli, 1996 [1531]) and The Prince (Dietz, 1986; Fallon, 1992; Ingersoll, 1986; Leonard, 1984; Pocock, 1985).

\section{MËTIS: UNPREDICTABILITY, AND THE INTELLIGENCE OF THE WEAK}

With the lion-fox metaphor, Machiavelli proposes the pre-classical concept of rationality or mettis 
dealing with the unpredictability of the political struggle in a changing world. Since to deal with political unpredictability requires that the princes rationality fosters his or her own unpredictability, foxes are the symbol of cunning rationality, or mètis, because they not only recognize snares, but are also pretenders, dissemblers, traitors, and are unpredictable (Machiavelli 1998, [1515], XVIII, XIX; see also Blanchard, 1984; Pitkin, 1984; Rebhorn, 1988). Lions are the symbol of strength.

Associated in Greek mythology and poetry (Homer, 1996; see Dobel, 2006; Detienne \& Vernant, 1978 [1976]; Dobel, 2006; Herzog, 2006), with the political concept of power, mêtis is a complex of flair, sagacity, foresight, flexibility of mind, resourcefulness, vigilant attention, the sense of opportunity, and extensive experience (Detienne \& Vernant, 1978 [1976]). Mètis is also a kind of practical knowledge, which involves calculation and thought, and allows ensuring the achievement and preservation of sovereign power when a political agent has to confront uncertainty and unpredictability. For example, Zeus's rationality, identified with cunning rationality (Herzog, 2006; Vernant, 1990), allows him to always guess the unexpected pitfalls, surprises, and traps that would threaten his power. Predicting or calculating the pitfalls, whose avoidance requires not only his pre-vision, but also practical action to prevent their success, allows Zeus to win and preserve power. That avoidance is not done, however, in a manner that is predictable from the perspective of his opponents. Zeus ought to be able to astutely anticipate the implementation of the wiles of his enemies, abort them, and thus preserve his power over the

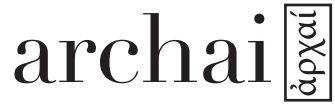

no 21, sep.-dec. 2017

Regina Queiroz, 'Mētis and violence in Machiavellian political theory', p. 223-250 


\section{archai圈}

no 21 , sep.-dec. 2017

Regina Queiroz, 'Mētis and violence in Machiavellian political theory', p. 223-250 gods of Olympus. From this perspective mètis is an informed prudence able to "foresee the unforeseeable” (Detienne \& Vernant, 1978 [1976], p. 27).

In addition, mètis arises in situations of confrontation and competition that can be gained through force - the stronger overcomes the weaker - or by cunning, in which the weaker manages against all odds to overcome the stronger (Detienne \& Vernant, 1978 [1976]; Dobel, 2006). The duel between Odysseus and the Cyclops is a clear example of cunning rationality, in which the strength of the Cyclops is defeated by the cunning of Odysseus. Clever and thoughtful, Odysseus was named Nobody, surprising and defeating the powerful Cyclops. Crying to the Cyclops, and asking for help, he said that Nobody kills him, by cunning and not by violence (Homer, 1996, 9, 414-455). Also, in those situations in which the weaker manages against all odds to defeat the stronger, the astute person is at the same time completely focused on current events and on a future in which he or she establishes some options in advance (Detienne \& Vernant, 1978 [1976]). Odysseus patiently waited for the moment to blind the Cyclops and when it arose, his full-minded focus on implementing his plan, allowed him to achieve his goal.

Besides the conflict between Odysseus and the Cyclops, the Trojan horse is another example of cunning rationality. Mentioned in The Odyssey (Homer, 1996, 8.84-95 and 11. 252ff), the Trojan horse was a snare that the Greeks used to enter the city of Troy and win the war. After a fruitless 10-year siege, the Greeks constructed a huge hollow wooden horse and hid warriors inside. Pretending to desert the 
war, they persuaded the Trojans that the horse was an offering to Athena (goddess of war) that would make Troy impregnable. The Trojans took the horse inside the city gates and that night the Greek warriors crept out of the horse and opened the gates to let in the returning Greek army. The Greeks entered and destroyed the city of Troy, decisively ending the war, as depicted in The Iliad (Homer, 2003).

Although in both cases Odysseus follows cunning rationality, there are two main differences between these cases. If The Iliad (Homer, 2003) shows us the absolute prevalence of the state of war (Jaeger, 1946 [1936]), The Odyssey (Homer, 1996) depicts Odysseus' vicissitudes in his everyday domestic life, after the war (Jaeger, 1946 [1936]). Indeed, the Trojan horse cunning occurs in a fierce conflict between the Trojans and Achaeans (the Greeks). The use of horse expedient, a means to win the war, was followed by the violent destruction of the city of Troy. The Nobody cunning snare takes place in The Odyssey, where Odysseus tries to recover multiple losses, his power, liberty, family, friends, and home. Odysseus blinds the Cyclops to escape from prison, and not as an attempt to conquer the Cyclops' island. Odysseus' vicissitudes in his everyday domestic life (Homer, 1996) and in the state of war (Homer, 2003) are led by mètis. However, cunning rationality (Homer, 2003) under the prevalence of the state of war not only implies violence, as it occurs in the fight between Odysseus and the Cyclops, but also the hubris of violence (e.g. The Greeks entered and destroyed the city of Troy). Mètis description under war includes one of the most disturbing features of the war, the possibility of annihilating the

\section{archai莀}

no 21 , sep.-dec. 2017

Regina Queiroz, 'Mētis and violence in $\mathrm{Ma}$ chiavellian political theory', p. 223-250 


\section{archai 䀥}

no 21 , sep.-dec. 2017

Regina Queiroz, 'Mētis and violence in $\mathrm{Ma}$ chiavellian political theory', p. 223-250 adversary. For instance, the difference between the domestic and the bellicose métis does not refer to the difference between a private or personal and political or public rationality, but to the difference between annihilating the adversary or not. From the perspective of bellicose rationality it would not be enough to blind the Cyclops. It would also be necessary to kill him and to destroy his island. Thus, if Odysseus had been led by the hubris of violence, mettis description in the Odyssey would correspond to bellicose and not domestic mètis. Similarly, if the Trojan war were led by domestic mettis, the Greeks would enter Troy, but not destroy it. They could imprison, or even kill, the politically powerful, but they would leave Troy intact. In other words, political rationality, as a public rationality, can be described under a domestic and bellicose rationality.

When approaching the Machiavellian concept of mettis we ought to have in mind these two different political contexts of the pre-classical and mythological tradition, more so than the wellknown Machiavellian analogy between politics and war (Dietz, 1986; Lukes, 2004; Mansfield, 1981). Cunning rationality of Machiavelli's prince results from the transfer into politics of the state of war's wiles, and his inheritance of pre-classic and mythological cunning rationality is mostly related with The Iliad (Homer, 2003). From this perspective, although Machiavelli politics does not dismiss the importance of peace in politics, political activity's main aim is to annihilate all the adversaries that threaten princes' acquisition and preservation of power. It is not casual when discoursing about the animal nature of princes (Machiavelli, 1998 [1515], 
XVIII) that Machiavelli explicitly refers to Achilles (Machiavelli, 1998 [1515], XVIII, p. 69), the hero of The Iliad (Homer, 2003). Achilles is linked to the leonine animal part of the prince, and fox cunning rationality is related to Achilles in the battle field and not to Odysseus' vicissitudes of domestic life. It is also not casual that Achilles is the model of princes who master the art of war (Machiavelli, 1998 [1515]), XIV, p. 60).

For now, and regardless of the two versions of cunning rationality, Machiavelli recurs to cunning rationality when he asks the prince to ally with time (Machiavelli, 1998 [1515], XXV). The recourse to cunning rationality is also present in: a) the description of the conquest of power by perfidy (Machiavelli, 1998 [1515], VIII); b) the behavior of nobles' "foresight and more astuteness" (Machiavelli, 1998 [1515], IX); c) the praise of the utility of the appearance of virtue (Machiavelli, 1998 [1515], XVIII); d) the emergence in time of the political action (Machiavelli, 1998 [1515], XXV); e) the fox's election as an essential feature of the prince's rationality (Machiavelli, 1998 [1515], XVIII); and finally the identification of Fortuna as an inconstant and unstable woman (Machiavelli, 1998 [1515], XXV), who represents the uncertainty in the struggle for power.

\section{MĒTIS: DECEPTIVE PRUDENT CUNNING RATIONALITY}

Besides mêtis' multiple, diverse, changing character, and its transfiguring and masking power (Machiavelli, 1998 [1515], XXV), we emphasize that the fox's attribution as an essential feature of the prince's rationality referring to his centauric nature

\section{archai蒡}

no 21, sep.-dec. 2017

Regina Queiroz, 'Mētis and violence in Machiavellian political theory', p. 223-250 


\section{archai圈}

no 21, sep.-dec. 2017

Regina Queiroz, 'Mētis and violence in Machiavellian political theory', p. 223-250 (half man and half beast (Machiavelli, 1998 [1515], XVIII, p. 69)), mainly to his half beast nature. Foxes help fierce lions to recognize snares (Machiavelli, 1998 [1515], XVIII), and to temper and moderate their ferocity (Machiavelli, 1998 [1515], XIX). Recognizing snares and tempering and moderating lions' ferocity allows for an understanding that not only is a cunning prince a prudent one, but also prudence can be seen as the excellence of the prince's cunning rationality.

Indeed, in the perspective of cunning rationality, prudence is a highly valuable virtue. In reality, on the one hand, mètis requires moderation, temperance, humanity, and wisdom (Machiavelli, 1998 [1515], XVII); on the other hand, cunning rationality implies capacity to foresee future events (Machiavelli, 1998 [1515], III). Finally, a good use of cruelty is related to the prudential rule of "picking the less bad as good” (Machiavelli, 1998 [1515], XXI, p. 91). This rule allows a carefully (prudent) measured application of cruelty, which excludes hatred, and can help them to acquire and preserve power. For instance, in the struggle for power and when they need to do evil, princes ought to follow the rule of "picking the less bad as good" (Machiavelli, 1998 [1515], XXI, p. 91). Guided by prudence (prudenzia), this rule allows that princes moderate and temper their cruel nature, and apply their cruelty well, to avoid losing power and life. For example, Antoninus [Caracalla] "ferocity and cruelty were so great and so unheard of - for after infinite individual killings he had put to death a great part of the people of Rome and all the people of Alexandria - that he became most hateful to all the world [...] so that he was killed by 
a centurion in the midst of his army" (Machiavelli, 1998 [1515], XIX, p. 79). Commodus and Maximinus had the same fate (Machiavelli, 1998 [1515], XIX). Since princes personify political community, Caracalla's homicide was not personal and private, but corresponds to the homicide of the political community.

In opposition to Antoninus [Caracalla], whose ferocity and cruelty were so great that he became most hateful to the entire world, Severus was able to mask his ferocity, and cruelty through deception. He dissimulated his aspiration to throne, pretended he was willing to share the throne with his enemy, Albinus, deceived the Senate by accusing Albinus of treachery, and had a pretext by which to take from him his government and life (Machiavelli, 1998 [1515], VII, VIII, XIX, p. 77-79). As prudent political rationality, Machiavellian bellicose cunning rationality also comprises deception, i.e. dissimulation, unpredictability, betrayal, infidelity, perfidy, corruption, and murder (Machiavelli, 1998 [1515], VII, VIII, XIX). For example, Machiavelli's bellicose cunning rationality foresight of the prince's rivals' attacks is complemented by those deceptive practices. When choosing the means by which to resist the destructive effects their enemies' attacks, princes ought first to anticipate the implementation of the wiles of the selfish politicians, and neutralize them. Second, they must themselves implement the snares (the wicked or nefarious designs - scelleratezza) to deceive their competitors and win political power.

In Machiavelli's political thought, prudence not only moderates ferocity and encourages deception,

\section{archai蒡}

no 21 , sep.-dec. 2017

Regina Queiroz, 'Mētis and violence in $\mathrm{Ma}$ chiavellian political theory', p. 223-250 


\section{archai圈}

no 21 , sep.-dec. 2017

Regina Queiroz, 'Mētis and violence in Machiavellian political theory', p. 223-250 but also limits the political effects of fidelity. Really, prudence required that princes ought to follow the rule of "breaking their promises". "A prudent lord, therefore, cannot observe faith, nor should he, when such observance turns against him, and the causes that made him promise have been eliminated" (Machiavelli, 1998 [1515], XVIII, p. 69). Since the acquisition or preservation of power under cunning rationality depends partially on prudence, when Machiavelli states that "[...] many peace treaties and promises have been rendered invalid and vain through the infidelity of princes; and the one who has known best how to use the fox has come out best" (Machiavelli, 1998 [1515], XVIII, p. 69-70), the relationship between prudence and bellicose cunning rationality is once again reaffirmed. "Picking the less bad as good" and "cannot observe the faith" are rules of a prudential cunning rationality. Thus, even if there is nowhere in Machiavellian political thought a clear statement about the virtue or the excellence of rationality, as it happens with phronesis in Aristotelian ethical and political thought (Aristotle, 1999, 2002), the prudent cunning rationality corresponds to a political virtuous reason. Consequently, although the concept of virtu defies definition, and is highly controversial in the political theory of Machiavelli (Fallon, 1992; Greene, 1986; Kahn, 1986; McCanles, 1983; Pocock, 1975), prudence designs the excellence of a prince's cunning rationality. For example, when dissimulating to aspire to the throne, pretending he was willing to share the throne with his enemy, and deceiving the Senate by accusing his rival Albinus of treachery, with the intent of taking from him his government and life (Machiavelli, 1998 [1515], XIX), Severus is the example of politically virtuous 
cunning rationality. Machiavelli explicitly says that "whoever examines minutely the actions of this man will find him a very fierce lion and a very astute fox" (Machiavelli, 1998 [1515], XIX, p. 79).

\section{Difficulties With BELLICOSE CUNNING RA- TIONALITY: INFLEXIBILITY AND THE HUBRIS OF VIOLENCE}

Cunning rationality may face difficulty in completely overcoming the destructive effects their enemies' attacks, not only because absolute foresight and the avoidance of fatal errors are humanly impossible, but also human beings also lack all the required virtues or the ability of a flexible use of virtues to face future troubles (Machiavelli, 1998 [1515], XXV). For example, even though the prince can be an extraordinary human being, "above the level of ordinary humanity" (Pocock, 1975, p. 170), he still remains human, and cannot avoid losing his or her power for reasons completely beyond his or her control. With Cesare Borgia's recourse to his wiles, crushing the Orsini (Machiavelli, 1998 [1515], VII), executing his swift and cruel Messer Remirro de Orco in Cesena Square (charging him for the full responsibility of political cruelties) (Machiavelli, 1998 [1515], VII), he overcame his enemies by force and fraud and exterminated those who had power or reason to hurt him. Given that Cesare Borgia committed only one error, choosing Pope Julius Second - "the duke erred in this choice and it was the cause of his ultimate ruin" (Machiavelli, 1998 [1515], VII, p. 33) - his exemplary deceptive practices were not enough to preserve his power. So, common mortals can learn from their mistakes, and mettis can be understood as the adequate rationality

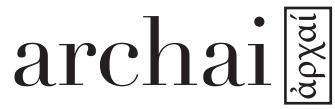

no 21 , sep.-dec. 2017

Regina Queiroz, 'Mētis and violence in Machiavellian political theory', p. 223-250 


\section{archai圈}

no 21, sep.-dec. 2017

Regina Queiroz, 'Mētis and violence in $\mathrm{Ma}$ chiavellian political theory', p. 223-250 for mere mortals in dangerous times, remaining "plausible today [because we are not] superman" (Dobel, 2006, p. 225) Machiavelli's description of the prince's rational behavior stresses, however, a peculiar feature of political life, namely not only that any mistake can risk the loss of his or her attempt to gain or preserve power, but that it is also irreparable.

Furthermore, despite the fact that prudence should govern fortune, the emphasis on prudence as cautiousness (Machiavelli, 1998 [1515], XXV) seems to challenge the princes' power. Among the not-always compatible meanings of prudence (e.g. the capacity to foresee future events, temperance and humanity, wisdom (Machiavelli, 1998 [1515], III, XVII, and XXI, respectively) the peculiar knowledge of prudence is mostly related to cautiousness (respetto) - which still remains in its modern conception (Annas, 1995; Nichols and White, 1999). Not only is being cautious opposed to having too much confidence (Machiavelli 1998 [1515], XVII), and to impetuosity (Machiavelli, 1998 [1515], XXV), but also the two qualities (cautiousness and impetuosity) are rarely attributes of a single individual. The vast majority of human beings are either one or the other. Nonetheless, when human beings do not possess both qualities, it is better to be impetuous that cautious, as "the cautious man, when it is time to come to impetuosity, does not know how to do it, hence comes to ruin" (Machiavelli, 1998 [1515], XXV, p. 100). Since the time to come to impetuosity is related to the overcoming of Fortuna, cautiousness deals with Fortuna with difficulty. Consequently, instead of helping the prince to overcome the abovementioned weaknesses, prudence as cautiousness 
also prevents the prince from dominating fortune, leading him to political defeat. Unlike the wise and prudent prince, the impetuous prince (e.g. "Julius [...] accomplished with his impetuous move what no other pontiff, with all human prudence, would ever have accomplished" (Machiavelli, 1998 [1515], XXV, p. 100). Truly, Machiavelli argues that if Pope Julius had needed to proceed with caution, he would be ruined (Machiavelli, 1998 [1515], XXV, p. 101). We have, then, to be cautious when over-evaluating the princes' impetuosity. Nevertheless, when Machiavelli clearly states "that it is better to be impetuous than cautious, because fortune is a woman; and it is necessary, if one wants to hold her down, to beat her and strike her down" (Machiavelli, 1998 [1515], XXV, p. 101), the equivalence between impetuosity and cautiousness is sustained with great difficulty.

Moreover, the fact of beating Fortuna and striking her down is not a negligible issue, because Fortuna represents the uncertainty, inconstancy and unpredictability in the struggle for power (Machiavelli, 1998 [1515], III, VI, VII, XIII, XXV). Consequently, when princes deal with uncertainty and unpredictability, the subordination of prudence or the excellence of cunning rationality to impetuosity entails, then, falling into violence and depriving princes of their polymorphic human nature, mainly their deceptive, but also prudent, adaptable, and unpredictable fox's cunning rationality.

In effect when prudence as cautiousness prevents the prince from dominating fortune, leading him to political defeat, the prince can always recur to laws (Machiavelli, 1998 [1515], XVIII). However,

\section{archai圈}

no 21 , sep.-dec. 2017

Regina Queiroz, 'Mētis and violence in $\mathrm{Ma}$ chiavellian political theory', p. 223-250 


\section{archai圈}

no 21, sep.-dec. 2017

Regina Queiroz, 'Mētis and violence in Machiavellian political theory', p. 223-250 cunning rationality, corresponding to the animal part of the prince, was justly invoked, because the juridical coercion of power is not enough to compel obedience (Machiavelli, 1998 [1515], XVIII). Thus, when laws, together with cunning rationality, do not allow winning or preserving power, princes seem to have no other choice than to appeal to the last resource available to him - not violence, but the hubris of violence. Actually, in Machiavellian political theory prudent cunning rationality is simultaneously related to the rules "picking the less bad as good" (Machiavelli, 1998 [1515], XXI, p. 91) and "breaking their promises" (Machiavelli, 1998 [1515], XVIII, p. 69-70). If, in accordance with the unpredictable nature of fortune, princes follow the rule of "to break promises", the withdrawal of cautions behavior implies giving up the rule "picking the less bad as good". When following this rule, the cautious prudent prince moderates the use of violence, to give up of prudence as caution, recurring to impetuosity, and implies that princes have no measure to apply cruelty. When princes rely on their own impetuous and fierce leonine nature, such as Pope Julius II's "ferocity and impetuosity" (Machiavelli 1998, XXV: 100), they lack any political measure offered by their prudent, cautious, and adaptable fox's cunning rationality. The impetuous and ruthless prince annihilates, then, his or her enemies beyond law and ruse.

The main problem with bellicose cunning rationality is not, however, to establish a relationship between political power and violence, or to attribute cruelty to the new prince, as Machiavelli did (Machiavelli, 1998 [1515], VIII, XVIII). On the contrary, 
Machiavellian crystalline acknowledgment that political power cannot be dissociated from violence (Arendt, 1954; Baker, 2009; Frazer and Hutchings, 2011; Minter, 1991; Tarlton, 2003; Wolin, 2004) can be seen as one of his main theoretical contributions to political theory and practice (Wolin, 2004). The awareness of violence as an unavoidable feature of political power can be tempered and moderated by the juridical and administrative political apparatus, relating political power to "an economy of violence" (Wolin, 2004, p.197-205). In addition, the construction of a community, mainly a new community, requires the use of "creative" violence inside or outside communities, when violence transforms into war. From this perspective, the immorality of cruel and deceptive practices is not a problem in itself. Thus, although the relationships between ethics with the political normativity in Machiavellian political theory, in general (Hösle, 1999; Pocock, 1975; Wolin, 2004), and between cunning rationality and morality, in particular (Herzog, 2006), are a matter of dispute, deceptive cunning rationality is beyond moral good and evil. This does not mean, however, that mêtis is beyond political good and evil - the greater political rational evil is the prince's falling into an unrestricted, unlimited, extreme, and uncontrolled violence. For example, the requirement to "break promises" can be ethically objectionable, but politically acceptable. Equally, the rules of "picking the less bad as good" (Machiavelli, 1998 [1515], XXI, p. 91) and "do benefits by little" (Machiavelli, 1998 [1515], VIII, p. 38) can also be politically justifiable. On the contrary, whatever its nature - realistic or rhetorical (Hariman, 1995) - the rule "to beat her [Fortuna] and strike

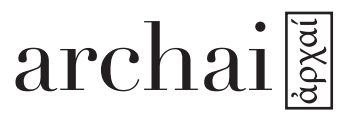

no 21, sep.-dec. 2017

Regina Queiroz, 'Mētis and violence in Machiavellian political theory', p. 223-250 


\section{archai 䀥}

no 21 , sep.-dec. 2017

Regina Queiroz, 'Mētis and violence in $\mathrm{Ma}$ chiavellian political theory', p. 223-250 her down" is politically undesirable. For instance, on the one hand, considering that the inconstancy and unpredictability of Fortuna also expresses the inconstancy and unpredictability of foxes, to "beat and strike down" subsumes any political endeavor by the requirement to definitively overcome unpredictable behaviors. On the other hand, accepting that cunning rationality is a practical knowledge, which allows a political agent to confront unpredictability without overcoming it definitively, the bellicose side of cunning rationality simultaneously expels astuteness and any quest of political measure. Thus, despite the fact that Machiavelli implicitly contrasts his theoretical political research with the utopian and idealistic philosophical approach of Plato (Machiavelli, 1998 [1515], XV), both approaches expel mètis. While Plato (1902) expelled mètis based on the requirements of a mathematical concept of rationality (Plato 1902), and Machiavelli expelled it based, mostly, on the prerequisite of violent force, both approaches conclude that mêtis cannot guide political reasoning.

BELlicose CUNNING RATIONALITY AS THE RATIONALITY OF THE STRONG

Since politicians have the power to definitively overcome unpredictable behaviors imposed on them, cunning rationality is not understood as the rationality of the weak or the "art of the weak" (De Certeau, Jameson, and Lovitt, 1980, 6; see also Detienne \& Vernant, 1978 [1976]; Dobel, 2006, Herzog, 2006), but that of the strong. Machiavellian bellicose conception of mettis subverts the underlying main assumption of mythological description of 
cunning rationality, which supposes that the deceptive practices of the weak (the Greeks or Odysseus) ought to be victorious over the force of the strong (The Trojans or the Cyclops).

To understand cunning rationality as the rationality of the strong seems, however, not politically sound.

First, as the rationality of the strong, cunning rationality gives the power to definitively overcome unpredictable behaviors. In effect, the bellicose conception of mettis, as the rationality of the strongest, is related to the belief that there is a complete political victory, in this case, over unpredictability. On the contrary, domestic deceptive practices of cunning rationality not only seem reasonable in everyday life, in which someone does not have the power to definitively overcome unpredictable behaviors imposed on her/him, but also can be seen as political deceptive practices of the weak. For example, De Certeau, Jameson, and Lovitt (1980) invoke cunning tactical rationality as the rationality of the weakest, contrasting it with the strategic rationality of the powerful. Tactics are calculated actions which are determined by the absence of a proper place. Strategies are a specific kind of knowing, which "transforms the uncertainties of history into readable spaces [and] gives the power of giving itself a proper place". From De Certeau, Jameson, and Lovitt's (1980) perspective the difference between strategy and tactics, along with the distinction between visibility and invisibility weaker are invisible - allows a space of resistance in public life, and seems fruitful to explain the avoidance of the hubris of violence. In opposition, Machiavelli

\section{archai圈}

no 21, sep.-dec. 2017

Regina Queiroz, 'Mētis and violence in $\mathrm{Ma}$ chiavellian political theory', p. 223-250 


\section{archai圈}

no 21 , sep.-dec. 2017

Regina Queiroz, 'Mētis and violence in Machiavellian political theory', p. 223-250 not only places deceptive practices against the real or imaginary enemies of the prince at the heart of power, he also identifies the locus of power with a great opacity, which can preclude political resistance. Symmetrically, even politicians cannot protect themselves against invisible enemies, and given that princes are not able to foresee their wiles, the "dread of annihilation" (Major, 2007) can transform the prince himself into a watchman, or even worse, a violent and paranoid political agent led by continuous suspicion. Even acknowledging the differences between the two approaches of mettis (e.g. the cunning intelligence to weak, and strategic intelligence to powerful), following Homer's The Odyssey (1996), De Certeau, Jameson, and Lovitt (1980) and offer a plausible conception of political cunning rationality, related to the powerless and not to the strongest.

Second, as the rationality of the strongest, deceptive prudent practices to thwart unpredictability increases suspicion and untruthfulness among political agents, which in turn creates a violent public realm, and isolates the prince from his community.

Third, bellicose cunning rationality implies if not the refusal of any political rationality, the victory of rationality of violence, whatever the rationality may be of this violence in Machiavellian thought. Even if $m e \bar{t}$ tis would not be expelled from political life, in the worst scenario bellicose cunning rationality can be seen as the proper rationality of violence, as Kenney (2010) has already evidenced.

Summing up, although Machiavellian crystalline acknowledgment that political power cannot 
be dissociated from violence can be seen as one of his main theoretical contributions to political theory and practice, instead of following a bellicose conception of métis, political rationality should follow the domestic one, such as introduced in The Odyssey (Homer 1996). Even if the political rationality under the domestic version does not avoid circumstantially the need of fierce impetuosity, the endless quest of a prudential measure to apply cruelty prevents overcoming definitively unpredictable behaviors, and allows a never-ending 'interplay' between unpredictability and power. Accordingly, the struggle for political power is better understood under a domestic version of mettis, along the analogy between politics and everyday life, than to the bellicose version of cunning rationality and the corresponding analogy between politics and war. Since this analogy reduces any political life to a matter of absolute destruction of the adversaries (e.g. The Greeks entered and destroyed the city of Troy), the struggle for political power is reduced to a fierce battle of impetuous political agents who lack any quest of political measure to fight against their adversaries. It is not surprising that the bellicose cunning rationality underlying that analogy plunges us into the abyss of violence's hubris.

Additionally, even if the hubris of violence could and should require rational calculation, the rationality under that unmeasured frame can be understood as imprudent, unwise, barbarian, and intemperate reason, i.e. as a vicious reason. Thus, beyond the unavoidable risk of different historical contexts - pre-classical antiquity, Renaissance, and the democratic and global world - the attempt to

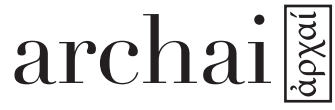

no 21, sep.-dec. 2017

Regina Queiroz, 'Mētis and violence in $\mathrm{Ma}$ chiavellian political theory', p. 223-250 


\section{archai 䀥}

no 21, sep.-dec. 2017

Regina Queiroz, 'Mētis and violence in Machiavellian political theory', p. 223-250 deal with unpredictability, intensifying it through endless bellicose practices, fosters the acquisition and preservation of power only with great difficulty. We remind the reader that Antoninus Caracalla's hubris of violence made him so hateful to all the world that he was killed. The acquisition and preservation of power is, then, better attained through a prudential cunning rationality, which subsumes all deceptive and bellicose practices under a quest of political measure. Therefore, the insufficiency of political wiles to vanquish unpredictable fortune ought not to be replaced by unmeasured political rationality. Otherwise, although one may acknowledge the risks of the hubris of violence (Machiavelli, 1998 [1515]), the impossibility of foreseeing princes' enemies' wiles, and the possibility of being defeated by them, allows annihilating any political adversary beyond law and mètis.

\section{Conclusion}

Mythological rationality to politics challenges mainly the political practice of a new prince, who builds a new principality or communities. Referring to a pre-classical conception of rationality, Machiavellian bellicose métis seems the most suitable political reasoning to deal with the unpredictability of political life, in general, and with the practice of a new prince, who builds a new principality or communities, in particular. Actually, although we agree with De Certeau, Jameson, and Lovitt's (1980) approach to mètis, which stresses the main features of the pre-classical conception of rationality, also referred to by Detienne and Vernant (1978 [1976]) and Herzog (2006), we sustain that the specific political approach of Machiavelli 
seems to be inconsistent with his main premises of political thought (e.g. the cautious and prudent use of cruelty). We also show that bellicose cunning rationality can also lead to violent hubris, simultaneously expels astuteness and any quest of political measure and fosters the acquisition and preservation of power only with great difficulty. Finally, although Machiavellian cunning rationality has limitations, it helps us to understand that bellicose cunning rationality cannot be a proper conception of political rationality in a changing and impermanent world.

Future research could analyze the differences and similarities between Machiavellian bellicose mètis and contemporary approaches of cunning rationality (Herzog 2006, Scott 1998) different from De Certeau, Jameson, and Lovitt (1984). Future research could also evaluate the theoretical contribution of these contemporary approaches to political theory and practice.

\section{REFERENCES}

ADAM, J. 1902. (ed.). The Republic of Plato. Cambridge. Cambridge University Press.

ANNAS, J. (1995). Prudence and morality in ancient and modern Ethics. Ethics 105, n ${ }^{\circ} .2$, p. 41 257. https://doi.org/10.1086/293699

ARENDT, H. (1954). Between Past and Future. New York, Penguin Book.

BAKER, J. (2009). Violence for equality: lessons from Machiavelli. Global Crime, 10, nº. 4, p. 306-319. https://doi.org/10.1080/17440570903248197

\section{archai莀}

no 21 , sep.-dec. 2017

Regina Queiroz, 'Mētis and violence in Machiavellian political theory', p. 223-250 


\section{archai圈}

no 21, sep.-dec. 2017
Regina Queiroz, 'Mètis and violence in $\mathrm{Ma}$ chiavellian political theory', p. 223-250
BENNER, E. (2014). Machiavelli's Prince: A New Reading. Oxford, Oxford University Press.

BLANCHARD, M. (1984). The Lion and the Fox. Politics and Autobiography in the Renaissance. Notebooks in Cultural Analysis, no. 1, p. 53-85.

De CERTEAU, M. JAMESON F and LOVITT, C. (1984). The Practice of Everyday Life. Berkeley, CA University of California Press.

DETIENNE, M. and VERNANT, J. P. (1978 [1976]). Cunning Intelligence in Greek Culture and Society (trans. Janet Lloyd). Chicago and London, The University of Chicago Press.

DIETZ, M. (1986). Trapping the Prince: Machiavelli and the Politics of Deception. The American Political Science Review, 80, no. 3, p. 777-799. https:// doi.org/10.2307/1960538

DOBEL, P. (2006). Mortal Leadership in Homer's Odyssey. Public Integrity, 8, nº. 3, p. 215-231. https:// doi.org/10.2753/PIN1099-9922080303

FALLON, S. (1992). Hunting the Fox: Equivocation and Authorial Duplicity in the Prince. PMLA, 107, n. 5, p. 1181-1195. https://doi.org/10.2307/462873

FRAZER, E. and HUTCHINGS, K. (2011). Virtuous Violence and the Politics of Statecraft in Machiavelli, Clausewitz and Weber. Political Studies, 59, nº. 1, p. 5673. https://doi.org/10.1111/j.1467-9248.2010.00841.x

GREENE, T. (1986). The End of Discourse in Machiavelli's Prince. In: Parker, P; Quint, D. (eds.), Baltimore, Johns Hopkins UP, p. 63-77. 
HARIMAN, R. (1995). Political Style: The Artistry of Power (New Practices of Inquiry). Chicago, University of Chicago Press. https://doi.org/10.7208/ chicago/9780226316284.001.0001

HERZOG, D. (2006). Cunning. New Jersey, Princeton University Press. https://doi.org/10.1007/ BF01430690

HOMER. (1996). The Odyssey (trans. by Robert Flages). New York, Viking.

HÖSLE, V. (1999). Morality and Politics: Reflections on Machiavelli's Prince. International Journal of Politics, Culture, and Society, 3, nº. 1, p. 51-69.

INGERSOLL, D. (1968). The Constant Prince. Private Interests and Public Goals in Machiavelli. The Western Political Quarterly, 21, $\mathrm{n}^{\circ}$. 4, p. 588-596. https://doi.org/10.2307/446750 https://doi.org/10.1177/106591296802100404

IRWIN, T. (1999). Aristotle. Nicomachean Ethics. Indianapolis Cambridge, Hackett Publishing Company Inc.

IRWIN, T. (2002) (ed.). Aristotle. The Politics (trans. Carnes Lord). Chicago, University of Chicago Press.

JAEGER, W. (1946 [1936]). Paideia. The Ideals of Greek Culture (trans. Gilbert Highet) vol. I. Oxford, Basil Blackwell.

KANH, V. (1986). Virtù and the example of Agathocles in Machiavelli's Prince. Representations, $\mathrm{n}^{\circ} .13$, p. 63-83.

\section{archai}

no 21, sep.-dec. 2017

Regina Queiroz, 'Mētis and violence in $\mathrm{Ma}$ chiavellian political theory', p. 223-250 


\section{archai圈}

no 21, sep.-dec. 2017

Regina Queiroz, 'Mētis and violence in Machiavellian political theory', p. 223-250
KENNEY, M. (2010). Beyond the Internet: Mètis, Techne, and the Limitations of Online Artifacts for Islamist Terrorists. Terrorism and Political Violence, 22, $\mathrm{n}^{\circ}$. 2, p.177-197.https://doi. org/10.1080/09546550903554760

LEONARD, J. (1984). Public versus private claims: Machiavellianism from Another Perspective. Political Theory, 12, $\mathrm{n}^{\mathrm{o}}$. 4, p. 491-506. https://doi. org/10.1177/0090591784012004002

LUKES, T. (2004). Martialing Machiavelli: Reassessing the Military Reflections. The Journal of Politics, 66, $\mathrm{n}^{\mathrm{o}} .4$, p. 1089-1108.https://doi.org/10.1111/ j.0022-3816.2004.00291.x

MACHIAVELLI, N. (1996 [1531]). Discourses on Livy (trans. Harvey Mansfield and Nathan Tarcov). Chicago, University of Chicago Press. https://doi. org/10.7208/chicago/9780226500331.001.0001

MACHIAVELLI, N. (1998 [1515]). The Prince (trans. Harvey Mansfield). Chicago, University of Chicago Press. https://doi.org/10.7208/chicago/9780226500508.001.0001

MAJOR, R. (2007). A New Argument for Morality. Political Research Quarterly, 60, nº. 2, p. 171-179. https://doi.org/10.1177/1065912907301705

MANSFIELD, H. (1981). Machiavelli's Political Science. The American Political Science Review, 75, no. 2, p. 293-305. https://doi.org/10.2307/1961365

McCANLES, M. (1983). The Discourse of Il Principe. Malibu, Undena. 
MINTER, A. (1991). Machiavelli, Violence and History. The Harvard Review of Philosophy, 2, $\mathrm{n}^{\circ}$. 1, p. 27-39.

NICHOLS, R. L.; WHITE, D. M. (1979). Politics Proper: On Action and Prudence. Ethics, 89, nº. 49, p. 372-384. https://doi.org/10.1086/292124

NIKODIMOV, G. (2006). Machiavel, penseur de l'action politique, In: Nikodimov, G.; Ménissier, T. (eds.), Lectures de Machiavel. Paris. Ellipse, p. 259-292.

PITKIN, H. (1984). Fortuna is a Woman. Berkeley, University of California Press.

POCOCK, J. (1975). The Machiavellian Moment: Florentine Political Thought and the Atlantic Republic Tradition. New Jersey, Princeton University Press. https://doi.org/10.1177/0090591785013004004

POCOCK, J. (1985). Machiavelli in the Liberal Cosmos. Political Theory, 13, no ${ }^{\circ}$ 4, p. 559-574.

REBHORN, W. (1988). Foxes and Lions. Machiavelli's Confidence Men. Ithaca, NY, Cornell University Press.

RIEU, P. (2003) (ed.). HOMER. The Iliad (trans. E.V. Rieu). London, Penguin Classics.

SCOTT, J. (1995). Seeing Like a State. How Certain Schemes to Improve the Human Condition Have Failed. New Haven and London, Yale University Press.

TARLTON, C. (2003). "Azioni in modo l'una dall'altra": action for actions'sake in Machiavelli's

\section{archai圈}

no 21, sep.-dec. 2017

Regina Queiroz, 'Mètis and violence in $\mathrm{Ma}$ chiavellian political theory', p. 223-250 


\section{archai圈}

no 21 , sep.-dec. 2017
The Prince [Political Action, Machiavelli, Virtù and Fortuna, The Prince, Political Causality]. History of European Ideas, n ${ }^{\circ} .29$, p. 123-140. https://doi. org/10.1016/S0191-6599(02)00106-7

VERNANT, J. P. (1990). Mythe et religion en Grèce ancienne. Paris, Seuil.

WOLIN, S. (2004). Politics and Vision: Continuity and Innovation in Western Political Thought, Boston, Little, Brown.

Submitted in October (2015) and accepted for publication in January, 2016 